\title{
Preliminary Study Of Local Catalyst For Low Cost Methanol Synthesis As Subsequence Process Of A Model System Of Biomass Fluidized Bed Catalytic Gasification
}

\author{
Joni Prasetyo ${ }^{1, *}$, Nurdiah Rahmawati ${ }^{1}$, Galuh Wirama Murti ${ }^{1}$, S.D. Sumbogo Murti ${ }^{1}$, Tyas Puspitarini ${ }^{1}$, Astri Pertiwi ${ }^{1}$, \\ Fusia Mirdayanti ${ }^{1}$, Erlan Rosyadi ${ }^{1}$, Herman Hidayat ${ }^{1}$, Adiarso ${ }^{1}$, Yuta Sudo $^{2}$, Reiji Noda $^{2}$ \\ ${ }^{1}$ Center of Energy Resources Technology and Chemical Industry, , Agency for the Assessment and Application of Technology, \\ Indonesia \\ ${ }^{2}$ Gunma Uniersity, Japan
}

\begin{abstract}
Biomass waste has been emerging as an alternative energy and fuel. Direct combustion of biomass leads to harmful substances such as NOx and CO which are environmentally unfriendly manner. Innovation of clean technologies like gasification would have a potential in developing technology to reduce the emissions of harmful substances into the environment. The syngas of biomass gasification is an intermediate product which can be converted further to various types of alternative fuels especially methanol. Agency for the Assessment and application of Technology (BBPT)-Indonesia in cooperation with Gunma University-Japan has been conducting assessment and application of environmentally friendly solid biomass wastes utilization technology under the SATREPS (Science and Technology Research Partnership for Sustainable Development) program. This work is a prolongation of biomass gasification process from empty fruit bunches (EFB) to produce syngas. Furthermore, the syngas has a potential as raw material to synthesize methanol. The study of methanol synthesis focused on the development of efficient and low-cost catalyst in term of low pressure and low temperature. The catalyst of methanol synthesis was prepared by co-precipitation method with copper basis. The experiments have been performed and tested in a once-through process by Low-Pressure Fixed Bed Reactor in Micromeritics unit at a mild operating condition. The result shows that catalyst $\mathrm{CuO}: \mathrm{ZnO}: \mathrm{Al}_{2} \mathrm{O}_{3}$ (47\%: 37\%: 15\%) has a good performance at 20 bar and $270^{\circ} \mathrm{C}$ with methanol concentration in the gas product up to $1.15 \%$. On the words, the local catalyst performance comparable with commercial catalysts at low pressure and low temperature.
\end{abstract}

\section{Introduction}

The treatment of biomass like Empty Fruit Bunch (EFB) of Palm by direct combustion results harmful gases such as $\mathrm{SO}_{2}, \mathrm{NOx}$, and $\mathrm{CO}$ [1]. Therefore, this treatment can be considered as not environmentally friendly manner. The technology development of biomass treatment is needed to minimize the pollutant. Regarding the environmental issues of direct combustion, a solution like gasification method can overcome this problem. On the other words, the development of gasification technology, is clean technology, can control the harmful gases [2-3]. The syngas can be used as raw material to methanol synthesis, a liquid fuel.

Micro process technology is one of the promising breakthroughs involving $\mathrm{Cu} / \mathrm{ZnO}$-support catalyst in the Integrated micro packed bed reactor-heat exchanger (IMPBRHE) [4-6]. In this process, CO which is one of the pollutants will act as reactant together with $\mathrm{H}_{2}$ and converted to methanol through a catalyzed process in the fixed bed reactor.

Several industries in Indonesia, which are mainly engaged in the catalytic industries, do not uses local catalyst but import. So far, the demand of the catalysts has been fulfilled by importing from advanced countries such as America, Japan, and Europe. This is the reason why Indonesia should be sovereign in producing its own local catalyst [7]. Therefore, innovation and development of catalyst is very important, should be sustained in Indonesia. The co-precipitation catalyst is expected to have superiority over impregnation catalyst because of higher concentration of surface active sites, and uniform dispersion active catalyst [8].

The first generation of methanol synthesis was carried out by high temperature and elevated pressure $\left(350^{\circ} \mathrm{C}\right.$ and $250-350$ bar) over $\mathrm{ZnO} / \mathrm{Cr}_{2} \mathrm{O}_{3}$ catalyst, 
which content $20-75 \% \mathrm{Zn}$. The catalytic process shows high activity and selectivity as well as resistance to sulphur toxicity from syngas of gasification. At further development of methanol synthesis process, sulphur content should be removed prior to the reactor so that $\mathrm{Cu}$-based catalysts can be used [9]. This method is still in current trend of methanol synthesis catalyst. The subsequent development should direct in the catalyst development for low temperature and pressure.

Previous work using impregnation catalyst gave a good result but still controlled by reaction rate rather than equilibrium condition [10]. By co-precipitation method, the catalyst was expected to reach equilibrium condition because of higher concentration $\mathrm{Cu}$ on surface active catalyst. This study focused on the development methanol synthesis catalyst at low pressure and low temperature and to optimize the process. The initiation study was carried out in a programme in Centre for Energy Resources and Chemical Industry (PTSEIKBPPT) that works to formulate the composition of catalyst to figure out the best performance in term of high productivity and high selectivity for methanol synthesis in fixed bed reactor.

\section{Methodology}

\subsection{Catalyst Preparation}

$\mathrm{Cu} / \mathrm{ZnO} / \gamma-\mathrm{Al}_{2} \mathrm{O}_{3}$ catalysts was prepared by impregnation method. $\mathrm{Cu}$-nitrate and $\mathrm{Zn}$-nitrate were raw materials that would be attached on $\gamma-\mathrm{Al}_{2} \mathrm{O}_{3}$ as the support as $\mathrm{Cu}$ and $\mathrm{ZnO}$. A part of $\mathrm{Cu}$ on the catalyst, would be oxidized, and written as $\mathrm{Cu}[\mathrm{Zn}]$. Afterward, from the $\mathrm{CuO}$ molecular would be in the form of $\mathrm{CuO} / \mathrm{ZnO}$ phase. Its reduction will be affected by $\mathrm{ZnO}$ [11].

The second method, $\mathrm{CuO}-\mathrm{ZnO}-\gamma-\mathrm{Al}_{2} \mathrm{O}_{3}$ catalysts were also prepared by co-precipitation method at neutral $\mathrm{pH}$ and temperature of $70^{\circ} \mathrm{C}$. The metal salt solution $\left(\left[\mathrm{Cu}^{2+}\right]\right.$ $\left.+\left[\mathrm{Zn}^{2+}\right]+\left[\mathrm{Al}^{3+}\right]\right)$ with a certain molarity was dropped into demineralized water and parallelized with the addition $1 \mathrm{M}$ sodium carbonate to neutralize the $\mathrm{pH}$. The precipitate was formed on neutral $\mathrm{pH}$. Afterward, the precipitate was rinsed several times with demineralized water to remove the remaining $\mathrm{Na}^{+}$ions and aged overnight at $110^{\circ} \mathrm{C}[12]$.

\subsection{Calibration of the Micromeritics Unit by GC}

The confirmation test of gas flowrate, $\mathrm{H}_{2} / \mathrm{CO}$ was set in the fixed bed reactor, Micromeritics unit. The flowrate was carried out by comparing the gas concentration in the sampling bag to the flowmeter indicator. The estimation of ratio gas flowrate of $\mathrm{H}_{2} / \mathrm{CO}$ to ratio gas concentration of $\mathrm{H}_{2} / \mathrm{CO}$ is shown in Fig. 1 .

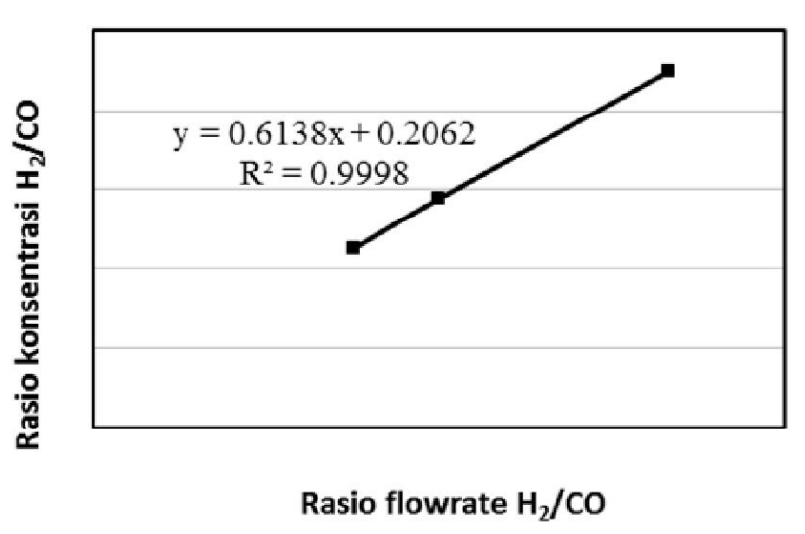

Fig. 1. Gas flowrate $\mathrm{H}_{2} / \mathrm{CO}$ calibration at micromerics unit

\subsection{Performance Test of Catalyst on the Micromeritics System}

The catalytic activity test was carried out in a continuous tubular fixed-bed micro-reactor as shown in Fig. 2. The operating condition was adjusted at pressure 20 bar and temperature $270^{\circ} \mathrm{C}$. A total of $1 \mathrm{gr}$ catalyst was filled in the tubular reactor. Prior to the reaction step, the catalyst was reduced with $\mathrm{H}_{2}$ flow at the operating temperature.

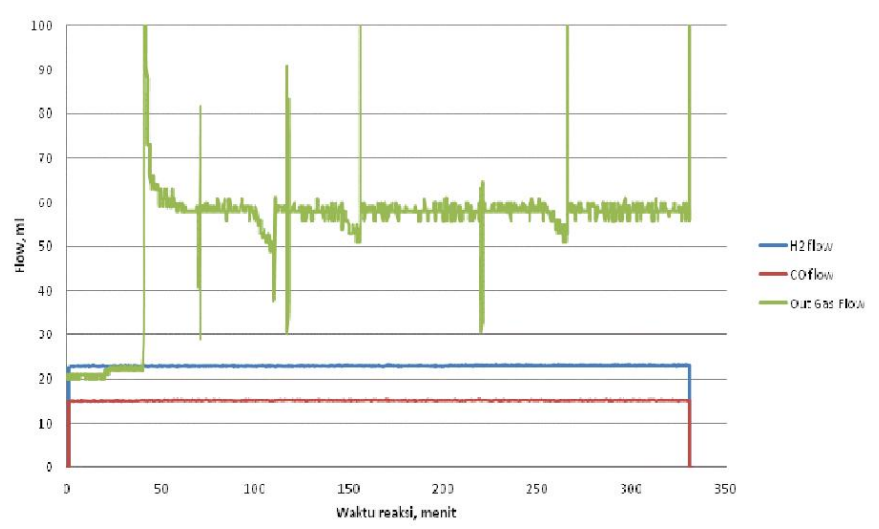

Fig. 2. Gas flowrate display versus retention time on methanol synthesis by using Micromeritics unit

\subsection{Physical Characterization by XRD}

X-ray diffraction (XRD) is an effective method for determining for the crystal structure of the catalyst. The XRD analyze was performed to show the domain area of crystals greater than 3-5 $\mathrm{nm}$. This arrangement will show the bulk crystal structure and the composition of chemical phase.

\section{Result and Discussion}

A single stoichiometric reaction of methanol synthesis is shown in equation 1 , an exothermic reaction.

$$
2 \mathrm{H}_{2}+\mathrm{CO} \stackrel{\mathrm{Cu} / \mathrm{ZnO}}{\Longleftrightarrow} \mathrm{CH}_{3} \mathrm{OH}
$$

According the stoichiometry, to obtain 1 mole $\mathrm{CH}_{3} \mathrm{OH}$ requires 2 moles of $\mathrm{H}_{2}$ and 1 mole of $\mathrm{CO}$. Based on the calibration curve, to get the ratio of $\mathrm{H}_{2} / \mathrm{CO} 2: 1$, the gas 
flow rates of $\mathrm{H}_{2}$ and $\mathrm{CO}$ were set at $22.57 \mathrm{ml} / \mathrm{min}$ and 15 $\mathrm{ml} / \mathrm{min}$, respectively. The catalytic activity was tested on four types methanol catalysts, 3 catalysts of $\mathrm{Cu}$-based catalyst were developed by PTSEIK-BPPT and one commercial catalyst. Some experiments was conducted for those four catalysts $\left(\mathrm{Cu}-\mathrm{ZnO} / \gamma-\mathrm{Al}_{2} \mathrm{O}_{3}\right.$ with the composition of $48: 37: 15 ; 53: 33: 14 ; 58: 30: 12)$ and another one was type of commercial catalyst as a control. Table 1 shows the test results of 4 types of catalysts that displayed in the concentration of methanol in the gas product.

Table 1. Performance test of catalyst for methanol production

\begin{tabular}{l|c}
\hline $\begin{array}{c}\text { Types of MeOH } \\
\text { catalysts }\end{array}$ & $\begin{array}{c}\text { Concentration of MeOH } \\
(\%)\end{array}$ \\
\hline Commercial & 0.26 \\
$48: 37: 15$ & 1.15 \\
$53: 33: 14$ & 0.28 \\
$58: 30: 12$ & 0.39 \\
\hline
\end{tabular}

Based on

Table 1, the performance of developed catalyst (48:37:15) was the best methanol synthesis from syngas. It was showed by obtaining the highest methanol concentration in the gas product at low cost process ,low temperature and pressure. However, the performance of commercial catalyst did not reach as high conversion as expected although it gave highest methanol product at higher temperature and pressure. Thus, the conversion to methanol did not reach equilibrium state at low temperature but influenced by reaction rate. That is the reason why the conversion was always increasing by higher temperature, the conversion was influenced by reaction rate not thermodynamic properties. Therefore, the suggestion is to prolong the retention time or make lower Gas Hourly Space Velocity (GHSV) to get closer to equilibrium state [13].

The methanol concentration in the gas outlet of micromeritic unit. The comparison among those result, the commercial catalyst and the developed catalysts especially for $\mathrm{Cu}-\mathrm{Zn} / \mathrm{Al}_{2} \mathrm{O}_{3}(48: 37: 15)$ during 4 hours is shown in Fig. 3. The methanol synthesis by local catalyst of $\mathrm{Cu}-\mathrm{Zn} / \mathrm{Al}_{2} \mathrm{O}_{3}$ (48:37:15) had the best performance among the others. It was indicated by higher methanol concentration in the gas product on every sampling. Therefore, it can be concluded that the developed catalyst performed more effective than the commercial catalyst at low pressure and low temperature.

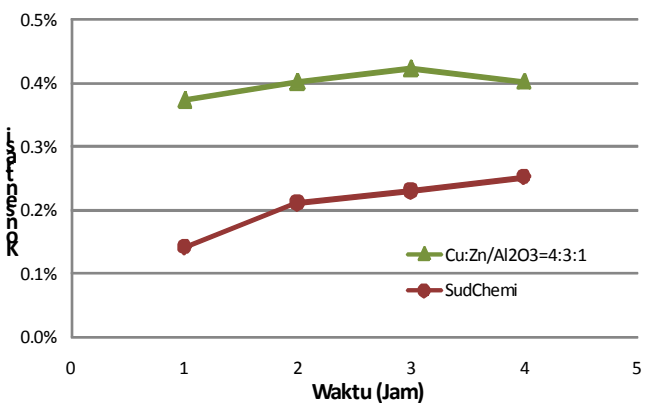

Fig. 3. The comparison of methanol concentration during the reaction over commercial catalyst
The increment of the catalyst effectiveness performance may due to the uniform distribution of $\mathrm{Cu}$ active metals catalyst on the surface of the support catalyst. Moreover, $\mathrm{ZnO}$ has a role as promoter preventing sintering so that active catalyst $\mathrm{Cu}$ distributed better and increase the selectivity towards methanol formation. Fig. 4 displays the XRD analysis of $\mathrm{Cu}$ $\mathrm{Zn} / \mathrm{Al}_{2} \mathrm{O}_{3}(48: 37: 15)$ catalyst.

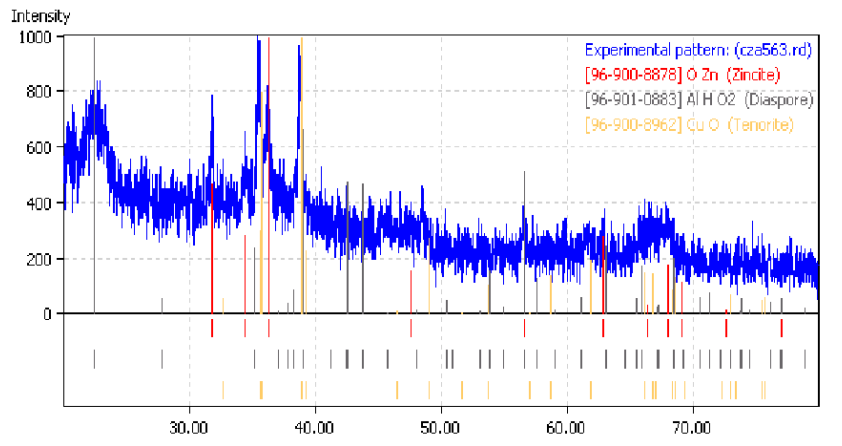

Cu-Ka $(1.541874$ A) 2thet:

Fig. 4. Diffraction profile $\mathrm{X}$-ray of $\mathrm{Cu}-\mathrm{Zn} / \mathrm{Al}_{2} \mathrm{O}_{3}(48: 37: 15)$.

According to statistical analysis related to the parameter structure, the data shows value

$$
\chi^{2}(\text { chi-squared })=1,097
$$

This value approved that the significant correlation between expected value for both the observations and the theories. $\chi^{2}$ with a value of 1.097 shows that the value $p$ $=0.05$ implying the probability of this result was only $5 \%$ coincidental, meanwhile $95 \%$ of the atomic structure of the crystalline phase and its orientation are fulfill the expectation. Based on the standard $p>0.05$ indicates that this value is in acceptable area. Thus, the hypothesis for $\chi^{2}$ of this sample shows that the result is significantly according to the theory.

To increase the conversion of methanol, double stoichiometric of $\mathrm{H}_{2}$ reactants was conducted during the reaction. The excess of $\mathrm{H}_{2}$ is expected to convert more $\mathrm{CO}$ into methanol. In the same operating condition, a commercial catalyst was examined and gave a positive result as shown in Fig. 5. The increasing of the methanol concentration up to $0.09 \%$ was obtained from $0.26 \%$ to $0.35 \%$ over the ratio $\mathrm{H}_{2}: \mathrm{CO}=1: 1$ and $\mathrm{H}_{2}: \mathrm{CO}=2: 1$, respectively.

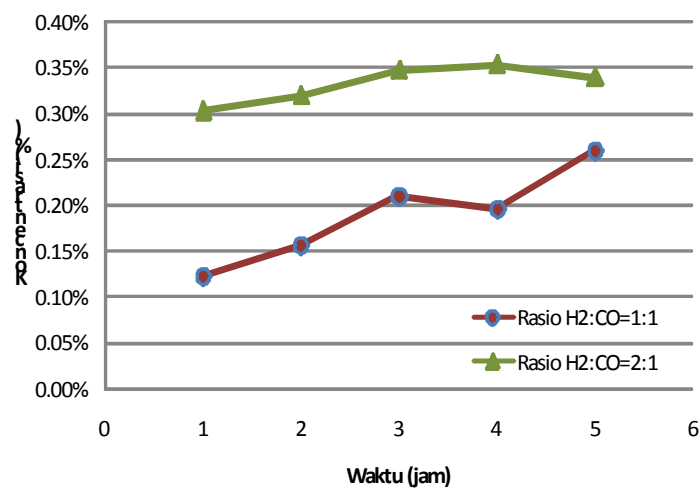

5. Double stoichiometric of $\mathrm{H}_{2}$ reactant on the methanol synthesis over commercial catalyst 
Implemented double stoichiometric for local catalyst $\mathrm{Cu}-\mathrm{Zn} / \mathrm{Al}_{2} \mathrm{O}_{3}$ (48:37:15) was delivered extraordinary results. By excess of $\mathrm{H}_{2}$, methanol concentration at fourth hour reached $1.15 \%$ far in excess that of commercial catalyst. Methanol synthesis by local catalyst is shown Fig. 6 proves the excess conversion to methanol over commercial catalyst.

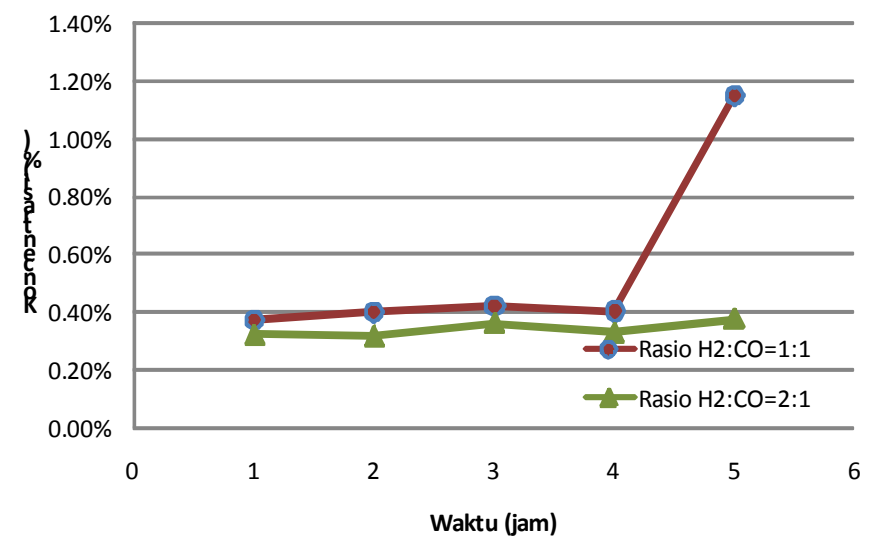

Fig. 6. Double stoichiometric of $\mathrm{H}_{2}$ reactant on the methanol synthesis over $\mathrm{Cu}-\mathrm{Zn} / \mathrm{Al}_{2} \mathrm{O}_{3}(48: 37: 15)$

\subsection{Shifting Reaction}

The existence of $\mathrm{CO}$ dan $\mathrm{H}_{2}$ in the environment with content humidity will cause shifting reaction, an equilibrium reaction. This condition give potential degradation for methanol since part of $\mathrm{CO}$ will be converted to $\mathrm{CO}_{2}$. Due to equilibrium shifting among reactants, the reformation reaction can also convert to $\mathrm{CO}_{2}$ as stated by equation 3 .

$$
\mathrm{H}_{2}+\mathrm{CO}_{2} \Leftrightarrow \mathrm{CO}+\mathrm{H}_{2} \mathrm{O}
$$

The absence of $\mathrm{CO}_{2}$ at the beginning will cause the formation of $\mathrm{CO}_{2}$. By excess of $\mathrm{H}_{2}$, the equilibrium will shift provide more to $\mathrm{CO}$ including water formation. It will affect the performance of methanol conversion.

The possible cause of low productivity methanol synthesis was a high gas flow rate which leads to shorter retention times of the reactants in the micromeritics which shown as high GHSV. The lower contact duration among the reactants and the catalyst in short time will result to low methanol conversion. All the reaction was interconnection and work in parallel.

As shown at Figure 7, the effect of $\mathrm{H}_{2}$ excess during the synthesis of methanol for 4 hours compiled over 3 types of the local-developed catalyst.

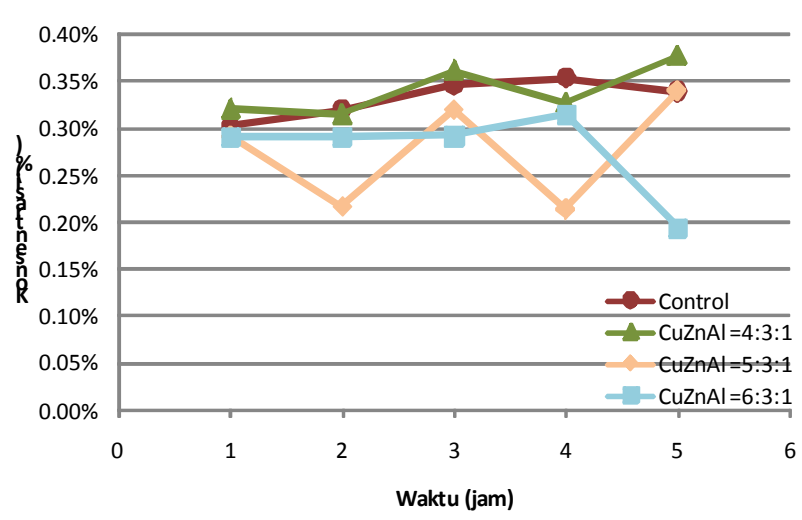

Figure 7. Double stoichiometric of $\mathrm{H}_{2}$ reactant on methanol production over the developed catalysts

During the reaction, the gas products such as $\mathrm{CO}_{2}$, DME, and $\mathrm{CH}_{4}$ were also formed and counted as by product. The by-products of hydrocarbons such as ethane or longer carbon chain compound were also generated but in very small amount so that they could be neglected.

Table 2 shows the selectivity of various types of catalysts to methanol products with the reactant of $\mathrm{H}_{2} / \mathrm{CO}=1: 1$. It can be seen that the $\mathrm{Cu}-\mathrm{Zn} / \mathrm{Al}_{2} \mathrm{O}_{3}$ (48:37:15) catalyst had the highest selectivity toward the methanol product compared to other catalysts.

Table 2. Selectivity of various types of catalysts towards the methanol products

\begin{tabular}{|c|c|c|c|c|c|}
\hline \multirow{2}{*}{$\begin{array}{c}\text { Types of } \\
\text { Cu:Zn:Al } \\
\text { catalyst (\%) }\end{array}$} & \multicolumn{4}{|c|}{ Concentration in the gas product } & \multirow{2}{*}{$\begin{array}{c}\mathrm{S} \\
(\mathrm{MeOH}) \\
(\%)\end{array}$} \\
\hline & $\begin{array}{c}\mathrm{MeOH} \\
(\%)\end{array}$ & $\begin{array}{l}\text { DME } \\
(\%)\end{array}$ & $\begin{array}{l}\mathrm{CH}_{4} \\
(\%)\end{array}$ & $\begin{array}{l}\mathrm{CO}_{2} \\
(\%)\end{array}$ & \\
\hline & & & & 1,882 & \\
\hline & & & & & 23,735 \\
\hline $53: 33$ & 0,2 & & 0,4 & 2,96 & 7,246 \\
\hline $58: 30: 12$ & 0,385 & 0,105 & 0,264 & 2,884 & 10,584 \\
\hline
\end{tabular}

The selectivity calculation of methanol for various types of the catalyst during the reaction with $100 \%$ excess $\mathrm{H}_{2}$ is shown in Table 3 . The selectivity of catalyst to methanol product was very different from other reaction with $\mathrm{H}_{2}: \mathrm{CO}=2: 1$. The $\mathrm{Cu}-\mathrm{ZnO} / \gamma-\mathrm{Al}_{2} \mathrm{O}_{3}$ catalyst $(58: 30: 12)$ has the highest methanol selectivity of $15.58 \%$, but this value is not greater than $\mathrm{Cu}-\mathrm{Zn} / \gamma$ $\mathrm{Al}_{2} \mathrm{O}_{3}$ catalyst (48:37:15) with a value of $23.74 \%$.

Table 3. Selectivity of various types of catalysts towards the methanol products by the excess of $\mathrm{H}_{2}$ reactant

\begin{tabular}{c|c|c|c|c|c}
\hline $\begin{array}{c}\text { Types of } \\
\text { Cu:Zn:Al } \\
\text { catalyst } \\
\text { (\%) }\end{array}$ & $\begin{array}{c}\text { Concentration in the gas product } \\
\mathbf{( \% )}\end{array}$ & $\begin{array}{c}\mathrm{DME} \\
\mathbf{( \% )}\end{array}$ & $\begin{array}{c}\mathrm{CH}_{4} \\
\mathbf{( \% )}\end{array}$ & $\begin{array}{c}\mathrm{CO}_{2} \\
\mathbf{( \% )}\end{array}$ & $\begin{array}{c}\text { S } \\
\mathbf{M e O H} \\
\mathbf{( \% )}\end{array}$ \\
\hline Commercial & 0,347 & 0,092 & 0,677 & 2,162 & 10,592 \\
$48: 37: 15$ & 0,377 & 0,094 & 0.483 & 2,933 & 9,706 \\
$53: 33: 14$ & 0,319 & 0,088 & 0,613 & 2,178 & 9,969 \\
$58: 30: 12$ & 0,314 & 0,044 & 0,461 & 1,199 & 15,580 \\
\hline
\end{tabular}

Overall, the average methanol productivity with $\mathrm{Cu}$ $\mathrm{Zn} / \gamma-\mathrm{Al}_{2} \mathrm{O}_{3}(48: 37: 15)$ was $0.38 \%$ slightly higher than the commercial catalyst by $0.35 \%$. 


\section{CONCLUSION}

The catalytic performance examinations for all developed and commercial catalysts were carried out in a low-pressure fixed-bed reactor. The standard operating condition was conducted in two conditions, based on the stoichiometric and $100 \%$ excess of $\mathrm{H}_{2}$ reactant, the average concentration of methanol produced over $\mathrm{Cu}$ $\mathrm{ZnO} / \gamma-\mathrm{Al}_{2} \mathrm{O}_{3}$ catalyst (48:37:15) was slightly higher than that of over the commercial catalyst. The best condition was achieved in the feed gas with the ratio of $\mathrm{H}_{2}: \mathrm{CO}=$ 2:1, where $\mathrm{Cu}-\mathrm{ZnO} / \mathrm{Al}_{2} \mathrm{O}_{3} \quad(48: 37: 15)$ catalyst was capable of producing gas products with a methanol concentration of $1.15 \%$, whereas by using the commercial catalyst, the methanol concentration produced was only $0.26 \%$.

There are some parameters that affecting the high performance of the developed catalyst. Firstly, the catalyst preparation technique has an impact on the productivity of methanol. The XRD analysis result shows that the $\mathrm{CuO}$ active metal was evenly distributed on the surface of the catalyst. This active metal determines the effectiveness of methanol formation. Meanwhile, $\mathrm{ZnO}$ as a promoter also plays a role in the catalyst activity by determining the level of selectivity of catalyst to form methanol.

In this preliminary study, there are several points that should be improved in order to get better results, namely:

1. Standardization of the catalyst preparation techniques is required to obtain a uniform catalyst.

2. The reliability of the catalyst needs to be examined for longer duration methanol synthesis. This endurance activity test is expected to provide results of the durability and deactivation study of the catalyst over the duration of the reaction.

3. A larger catalyst preparation needs to be assessed if the catalytic activity tests are conducted on a larger scale.

This work is supported by Science \& Technology Research Partnership for Sustainable Development (SATREPS) : Project for Development of a Model System for Fluidized Bed Catalytic Gasification of Biomass Wastes and Following Liquid Fuel Production in Indonesia. This project is joint research between Japan-Indonesia and in coordination mainly by Gunma University in Japan and PTSEIK-BPPT in Indonesia.

\section{References}

1. Wahyono, S., Sahwandan, F.L. and Suryanto, F., J. Tek.Lingkungan, PTL-BPPT, 64-74, (2008).

2. Blesl, M, et.al., Syngas Production from Coal, ETSAP, (2010).

3. Botha, F., Dobson, R., Harms, T., Jour. Energy in Southern Africa, 24, 2, (2013).

4. Bakhtiary-Davijany, H. et al., Chem. Eng. Jour., 167, 2-3, 496-503, (2011).

5. Bakhtiary-Davijany, H. et al., Chem. Eng. Sc., (2011).
6. Bakhtiary-Davijany, H. et al., , Ind. and Eng. Chem. Res. Jour., (2011).

7. Subagjo, Wujudkan Kemandirian Indonesia akan Kebutuhan Katalis untuk Industri, ITB, Bandung, (2013).

8. Liu, F. et al., J. Phys. Chem., 111, 20, 7396-7402, (2007).

9. Fiedler E, Grossmann G, Kersebohm D.B., Weiss G., and Witte C., Ullmann's Encyclopedia of Industrial Chemistry, Methanol, W.-V. V. G. C. KGaA, (2003)

10. Prasetyo, J. et al., AIP Conference Proceeding, 2001, 1, 04005-1 - 040005-8.

11. Robinson, WRAM, Mol, JC, , Appl. Cat., 60, 1, 6172, (1990).

12. Jingfa D., Qi S., Yulong Z., Songying C., Dong W., Appl. Cat., 139, 75-85, (1996).

13. Subagjo, Chemical Engineering Department, ITB, Indonesia (private communication). 